Global Journal of Business and Social Science Review

Journal homepage: http://gatrenterprise.com/GATRJournals/index.html

\title{
The Role of Union Leader-Member Relationship Capital within Trade Union for Mental Health
}

\author{
Jacqueline Koh ${ }^{1^{*}}$, Lailawati Mohd Salleh ${ }^{2}$, Naresh Kumar $^{3}$, Zuraina Dato' Mansor ${ }^{4}$, Noorziah \\ Mohd Salleh ${ }^{5}$, Dg Kamisah Ag Budin ${ }^{6}$, Abdul Kadir Rosline ${ }^{7}$ and Balakrisnan Parasuraman ${ }^{8}$ \\ ${ }^{1}$ Universiti Putra Malaysia/Universiti Teknologi Mara, Sabah, Malaysia \\ ${ }^{2,4}$ Universiti Putra Malaysia, Malaysia \\ 3,8 Universiti Malaysia Kelantan, Malaysia \\ 5,6,7 Universiti Teknologi Mara, Sabah, Malaysia
}

\begin{abstract}
Objective - There are three main objectives of this study. First, this study is to examine the influence of union effectiveness and perceived union support on union relationship capital to achieve positive mental health in the workplace. Next, this study is to investigate the interdependency of the dimensions of union relationship capital: communication, trust and commitment between the union leader and union members in improving and strengthening the relationship within the union. Lastly, this study is to investigate the role of relationship capital as the mediator between union effectiveness, perceived union support and mental health.

Methodology/Technique - A total of 600 questionnaires completed by trade union leaders and members in manufacturing sector based in Peninsular Malaysia were analysed using SEM (AMOS) and SPSS. The relationship between union effectiveness, perceived union support, union relationship capital and mental health were analysed using SEM. But the interaction between communication, trust and commitment were analysed using SPSS.

Findings - The results demonstrated that union effectiveness and perceived union support are determinants for union relationship capital. The finding showed that communication, trust and commitment are interdependent. Furthermore, the finding also shows a significant relationship between union relationship capital and mental health.

Novelty - It is said that good communication, trust and commitment within the trade union can increase cohesiveness and strengthen the trade union. A strong union can lead to positive mental health in the workplace.
\end{abstract}

Type of Paper: Empirical

Keywords: Union Leader- Member Relationship Capital, Mental Health, Malaysia.

JEL Classification: I10, I19.

\section{Introduction}

An employee is an asset to organization who contributes to the prosperity of an organization. The employee with a good state of mind is also a happy employee. A happy employee is crucial because it has direct influence on an individual performance such as higher productivity (Sharifzadeh \& Almaraz, 2014) and high efficiency (Sirisunhirun \& Dhirathiti, 2015; Chang \& Hsu, 2015). Furthermore, a happy employee can concentrate on

\footnotetext{
* Paper Info: Revised: September 14, 2016

Accepted: October 21, 2016

* Corresponding author:

E-mail: Jacque_1810@yahoo.com

Affiliation: Universiti Putra Malaysia/Universiti Teknologi Mara Malaysia, Malaysia.
} 
completing their task (Sharifzadeh \& Almaraz, 2014). However, globally we face many problems associated with poor mental health in workplace such as high numbers of accidents, injuries and death (Cottini, \& Lucifora, 2013; Burton, Schultz, Chen \& Edingthon, 2008; Goswami, 2015; O’Keefe, Brown \& Christaiona, 2014). International Labour Organization (ILO) claimed that organizations throughout the world are facing around 6,300 employee deaths daily due to occupational accidents or illness (ILO: Safety at Work, 2012). It is said that this statistic is even higher in developing countries (ILO: Safety at Work, 2012; Soehod \& Lekha, 2007). A similar problem occurred in Malaysia. According to the statistic provided by Malaysian Social Security Organization, there were 61,552 cases of accidents in 2012 with total compensation estimated to RM2,000 million (Malaysia Social Security Organization Annual Report, 2012). Higher accidents, injuries, and death in workplace bring great losses to organization in varies ways such as loss of productivity due to absenteeism and presenteeism (Smith, Black, Keegel \& Collie, 2014; Burton, Schultz, Chen \& Edingthon, 2008; Goswami, 2015; O'Keefe, Brown \& Christaiona, 2014). Factors can contribute to poor mental health includes poor terms and conditions of employment such as poor salary and benefits compensation (Kaewanuchit, Muntaner, \& Isha, 2015; Williams \& Rosenstock, 2015; Sveinsdottir, Biering, \& Ramel, 2006; Lo \& Lam, 2005), job insecurity (Huang et al., 2012; Burchell 2011; Sjöberg 2010) and long working hour (long working hours (Kivimäki, Virtanen, Kawachi, Nyberg, Alfredsson, Batty, Bjorner, Borritz, Brunner, Burr, Dragano, Ferrie, Fransson, Hamer, Heikkilä, Knutsson, Koskenvuo, Madsen, Nielsen, Nordin, Oksanen, Pejtersen, Pentti, Rugulies, Salo, Siegrist, Steptoe, Suominen, Theorell, Vahtera, Westerholm, Westerlund, Singh-Manoux, \& Jokela, 2015; Tayama, Li, \& Munakata, 2016; Valcour, 2007). A trade union identify as one of the main mechanism to overcome the problems. The trade union is the employee representative who has the legal right to negotiate and bargain on the terms and conditions of employment with the management. However, trade union which supposed to be strong is generally weak throughout the world (Hayter, Fashoyin \&Kochan, 2011; Gollan, 2006; Kuruvilla, Das, Kwon \& Kwon, 2002; Machin, 2000). Weak trade union makes union unable to fight and protect the interest of the employee. Hence, this study is to propose ways to strengthen union by investigating the relationship between union effectiveness, perceived union support, union relationship capital which consists of communication, trust and commitment between trade union leaders and members in order to achieve positive mental health in the workplace.

Studies in union setting stressed the important of union commitment and union participation for the strength and survival (Gall \& Fiorito, 2012; Fiorito \& Jarley, 2008). Past studies claimed that union commitment has a positive influence on union communication which includes union participation (Line and Lamane, 2014). It is said that good commitment within the trade union can affect their participation in union's activities that is vital for the union survival (Barling et al, 1992). Line and Lamane (2014) in their study found that poor communication within the union can affect the member's commitment towards the union. Furthermore, Drucker (2007) claim the important role of communication which includes union participation to install trust within the union. Past studies in the union setting mostly examine the dyadic relationship between communication, commitment, and trust: communication and commitment (Line \& Lamane, 2014; Clark, 2009), communication and trust (Drucker, 2007) and few examine the relationship of commitment with trust. However, personal relationship theory which introduced by Kelley (1979) claimed that communication, trust and commitment are cyclical and interdependent. Studies conducted by Sambasivan, Loke, Mohamed and Leong (2011) and Ramadass (2013; 2014) showed that these three elements are interacting with each other. They suggest that the interaction between communication, trust and commitment can maintain the long-term and quality relationship. Furthermore, these interactions can yield to positive outcomes (Kelley, 1979; Othmae 1992; Sambasivan, Loke, Sambasivan \& Downe, 2009) such as mental health. Thus, this study is to investigate the interaction of communication, trust, and commitment for relationships between trade union leader and trade union members (union relationship capital) in a single study to strengthen and increase the bargaining power of trade union for positive mental health. 


\subsection{Literature Hypotheses and Framework}

\section{Union Effectiveness and Union Relationship Capital}

Economic exchange theory described a relationship as an exchange on tangible or explicit elements between partners, which has influence on trust and well-defined commitment (Blau, 1964). In a union setting, the relationship between the union leader and union members can be conceptualised as an economic exchange. The member's perception of the effectiveness of union leaders in improving the terms and conditions of employment such as wage, compensation and good working conditions can increase the union member's trust towards their union. In return, the union members are committed to their union. Committed members tend to involve in union activities. Union activities includes attending trade union meetings and voting for collective bargaining (Barling, Fullagar \& Kelloway, 1992; Klandermans 1997). Therefore, it can be said that the regular exchange between union leaders and union members due to union effectiveness can enhance the union member's commitment and trust to the union. Based on this assumption, the relationship between union effectiveness and union relationship capital can be hypothesis as below:

\section{H1: Union effectiveness has positive influence on union relationship capital}

\section{Perceived Union Support and Union Relationship Capital}

Drawing from social exchange theory, perceived organizational support is referring to the employee perception towards their organization as supportive, care and value their contribution to the organization (Eisenberger, Huntington, Hutchison \& Sowa, 1986; Rhoades \& Eisenberger 2002; Aselage \& Eisenberger 2003). An exchange on socio-emotions can make the employee felt obligated to the organization that can enhance their trust level to their organization. Translating this concept into union setting, perceived union support defined as the union member's perception towards the union support and committed to their wellbeing. Previous studies found that regular exchange of socio-emotional between union leaders and union members can increase members' loyalty and commitment to the union (Shore, Tetrick, Sinclair \& Newton, 1994; Fuller, et al. 2001; Tetrick, Shore et al. 2007). Therefore, perceived union support is hypothesised to enhance the union relationship capital as below:

\section{H2: Perceived union support has positive influence on union relationship capital}

\section{Union Relationship Capital: Trust, Communication and Commitment Are Inter-Related}

Personal relationship theory stressed the important of communication, trust and commitment (relationship capital) for a successful relationship between partners such as husband and wife (Kelley, 1979), public sector collaboration (Ramadass, 2013; 2014) and strategic alliances (Sambasivan, Loke, Mohamed \& Yee, 2011; Loke, Sambasivan \& Downe, 2009). Kelley (1979) claim that communication, trust and commitment are cyclical and cannot stand alone without the other elements. Applying this concept in union context, union relationship capital refers to interrelated of communication, trust, and commitment within the union. Union relationship capital is crucial to enhance cohesiveness, strengthen and maintain long term between the union and union members. Literature in union setting revealed the important role of communication as a mechanism to develop the relationships within the trade union (Mohamed, Shamsudin \& Johari, 2010). Efficient and quality of communication between the union leaders and union members can boost the union members' trust (Line \& Lasmane, 2014) and commitment (Johari, Ghazali, 2011). Therefore, this relationship can be hypothesised as:

\section{H3: trust, communication and commitment between the union leader and union members are inter- related}




\section{Union Relationship Capital and Mental Health}

The exchange relationship between union leader and union members can be describe by the exchange between leader and member in the organizational setting. Social exchange theory stated that effective exchange between leader and member can influence mental health (Bell and Menguc, 2002). Past studies found that employee's mental health was improved through effective communication, trust and commitment (Wilson, Dejoy, Vandenberg, Richardson, \& McGrath, 2004; Nelson, Basu, \& Purdie, 1998). Furthermore, Kelley (1979), in personal relationship theory reveal the interrelated between communication, trust and commitment. These interdependency can leads to positive outcomes (Ramadass, 2013, 2014; Davis, \& Love, 2011; Sambasivan et. al, 2011) such as mental health. Based on this argument, the interrelated between communication, trust and commitment within the union can enhance mental health. This relationship can be hypothesized as follows:

\section{H4: Union relationship capital has a positive influence on mental health}

\section{The Mediating Role of Union Relationship Capital between Union Effectiveness, Perceived Union Support and Mental Health}

Both union instrumentality and perceived union support are the predictor to communication, trust and commitment within the union (union relationship capital) (Blau, 1964; Kuwabara, 2011). Union effectiveness and perceived union support are described as the union member's perception towards the union leaders. The capability of the union leaders in protecting the union members' right and interest can affect the union member's perception towards the union leader. Regular exchange of economic elements which includes salary, compensation, and job security can increase the union member's commitment and trust towards the union leader. Furthermore, the union member's perception on the union support on their wellbeing can also affect union relationship capital (Eisenberger, Huntington, Hutchison \& Sowa, 1986; Rhoades \& Eisenberger 2002; Aselage \& Eisenberger 2003). Frequent exchange of socio-emotions elements within the union can enhance trust and commitment within the union. Good communication, trust, and commitment between the union leaders and members due to union effectiveness and perceived union support can lead to positive mental health in organization (Wilson, Dejoy, Vandenberg, Richardson, \& McGrath, 2004; Nelson, Basu, \& Purdie, 1988; Bell and Menguc, 2002). Kelley (1979) suggested that the interdependency of communication, trust and commitment between partners such as union leaders and members can strengthen relationship. This can yield to positive outcomes like mental health. Thus the role of union relationship capital as the mediator for union effective, perceived union support and mental health are as below:

\section{H5: Union relationship capital mediates the relationship between union effectiveness and mental health \\ H6: Union relationship capital mediates the relationship between perceived union support and mental health}

\section{Method}

\section{Sample Size}

The population of union leaders and union members in Malaysia, $\mathrm{N}=913,169$. This study decided to use the n=384 as sample size generated from Krejcie and Morgan's (1970) sample size table. However, this study inflated the 384 sample size by $40 \%$. Thus, the sample size totalled up to and finally was rounded to 500 . The sample size was inflated to overcome problems that might occur due to incomplete questionnaire and low response rate 
(Neuman, 2003). In order to increase the response rate, the researcher has decided to increase the sample size to 600 respondents.

\section{Data Collection Procedures}

The questionnaire was available in both English and Bahasa's version. The Bahasa questions version was translated back to back to ensure the accuracy of the translation. The questionnaire was courier to the selected in-house union in Peninsular Malaysia. This courier includes the questionnaire, an introduction letter and informed consent letter in a booklet form. The respondents were asked to complete the questionnaires and return it back to the union office. The researcher personally collected the couriered questionnaire two weeks after distribution to ensure the higher response rate. Pos Express Malaysia envelopes with self-address also provided to respondents who haven't finished answering the questionnaire during the collection time. Later, the union officers sent the complete questionnaires using the Pos Express Malaysia to researcher. The response rate turned out to be high. Out of 600 questionnaires distributed $82.33 \%$ (494) questionnaires were usable. Table 2 describes the respondent's profile for this study.

\section{Measures}

This study used questionnaires as the research instrument. The questionnaires were divided into five sections: Section A (respondent's profile); Section B (union effectiveness); Section C (perceived union support); Section D (union relationship capital) and Section E (mental health). A 5-point Likert scale was used to indicate the respondent's scale of agreement on the items for every section. The scale ranged from (1) strongly disagree to (5) strongly agree. Table 1 provides the sources of items adapted for measurement in this study.

Table 1: Sources Referred for the Measurement (Dimensions and Items)

\begin{tabular}{lcl}
\hline Construct & Question Items & Source \\
\hline & \multirow{3}{*}{16} & Chacko (1985), De Cotiis \& Le Louarn (1981), \\
Union Effectiveness & & Fullagar \& Barling, (1989), \\
& 8 & Kochan, (1979) \\
Perceived Union Support & 12 & Sisenberger et al. (1986) \\
Union Relationship Capital & 12 & Goldberg (1972) \\
Mental Health &
\end{tabular}

\section{Data Analysis}

Structural Equation Modelling (SEM) using Analysis of Moment Structures (AMOS) 19.0 software was used to analyse the causal relationship between union instrumentality, perceived union support, union relationship capital and mental health. SPSS correlation analysis was used to analyse the interaction of communication, trust and commitment between the union leaders and union members.

\section{Results}

\section{Descriptive Findings}

Union members and union officers are the respondents of this study. Out of the 494 respondents, the majority were male $(65.99 \%)$ and only $34.01 \%$ are female. The age range for respondents mostly are within 31 to 40 years old (190 respondents) and between 41 to 50 years old (144 respondents). Most respondents have between 10-15 
years' length of service (23.5\%). Table 2 detailed the distribution of respondents by gender, age group and length of service.

\section{Model Testing}

To test the research framework, this study analyse the measurement model and structural model as suggested by Chin (2010) and Anderson and Gerbing (1988). This test starts with analysing the measurement model and followed by the structural model. The purpose of measurement model is to calculate the construct validity and good fit before going to the structural model. The structural model is to test the path coefficients or relationship between constructs. Figure 2 show the measurement model. From the results in measurement model, the convergent validity and discriminant validity were assessed. The model fit for measurement model is showed in Table 3. Fit statistics need to be assessing to ensure the proposed model is a fit to the data for the next test. All constructs of the confirmatory factor analysis (CFA) for measurement model were in the satisfactory fit indices.

Table 2: Distribution of Respondents by Gender, Age Group and Length of Service (N=494)

\begin{tabular}{lcc}
\hline Variable & Frequency & \% \\
\hline Gender & 326 & 65.99 \\
Male & 168 & 34.01 \\
Female & & \\
& 5 & 1.0 \\
Age & 103 & 20.9 \\
21 years and below & 190 & 38.4 \\
21-30 years & 144 & 29.1 \\
31-40 years & 50 & 10.1 \\
41-50 years & 2 & 0.4 \\
51-60 years & & \\
61 years and above & 38 & 7.7 \\
& 41 & 8.3 \\
Length of Service & 81 & 16.4 \\
Below 3 years & 116 & 23.5 \\
3-5 years & 107 & 21.7 \\
6-10 years & 72 & 14.6 \\
10-15 years & 39 & 7.9 \\
16-20 years & & \\
26 years and above & &
\end{tabular}

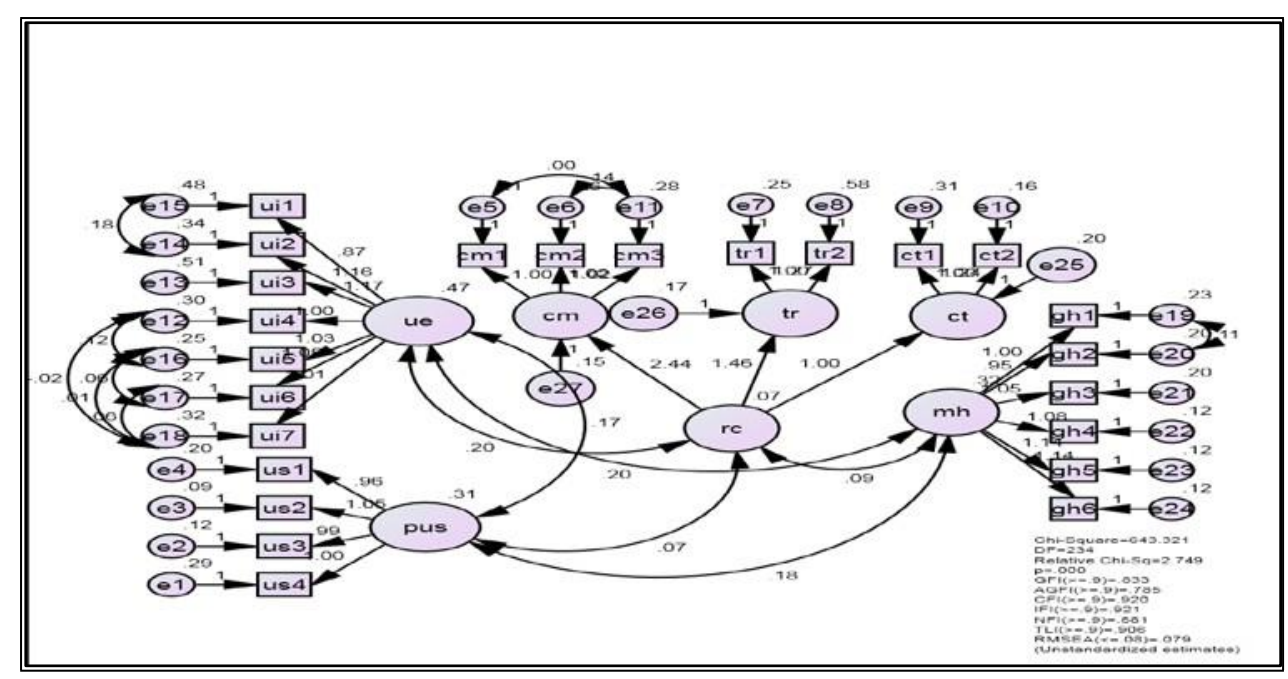

Figure 2: Measurement Model (Confirmatory Factor Analysis (CFA) for Measurement Model) 
Table 3: Model fit for measurement model

\begin{tabular}{|c|c|c|c|c|c|}
\hline \multicolumn{7}{|c|}{ Overall Model Fit Indices } \\
\hline & $\chi \mathbf{2 / d . f}$ & CFI & NFI & TLI & RMSEA \\
\hline $\begin{array}{c}\text { Acceptable Scale for } \\
\text { Good as well as } \\
\text { Adequate Fit }\end{array}$ & $\leq 5$ & $\geq 0.90$ & $\geq 0.90$ & $\geq 0.90$ & $\leq 0.08$ \\
\hline Composed Model Fit & 1.871 & 0.908 & 0.822 & 0.902 & 0.056 \\
\hline
\end{tabular}

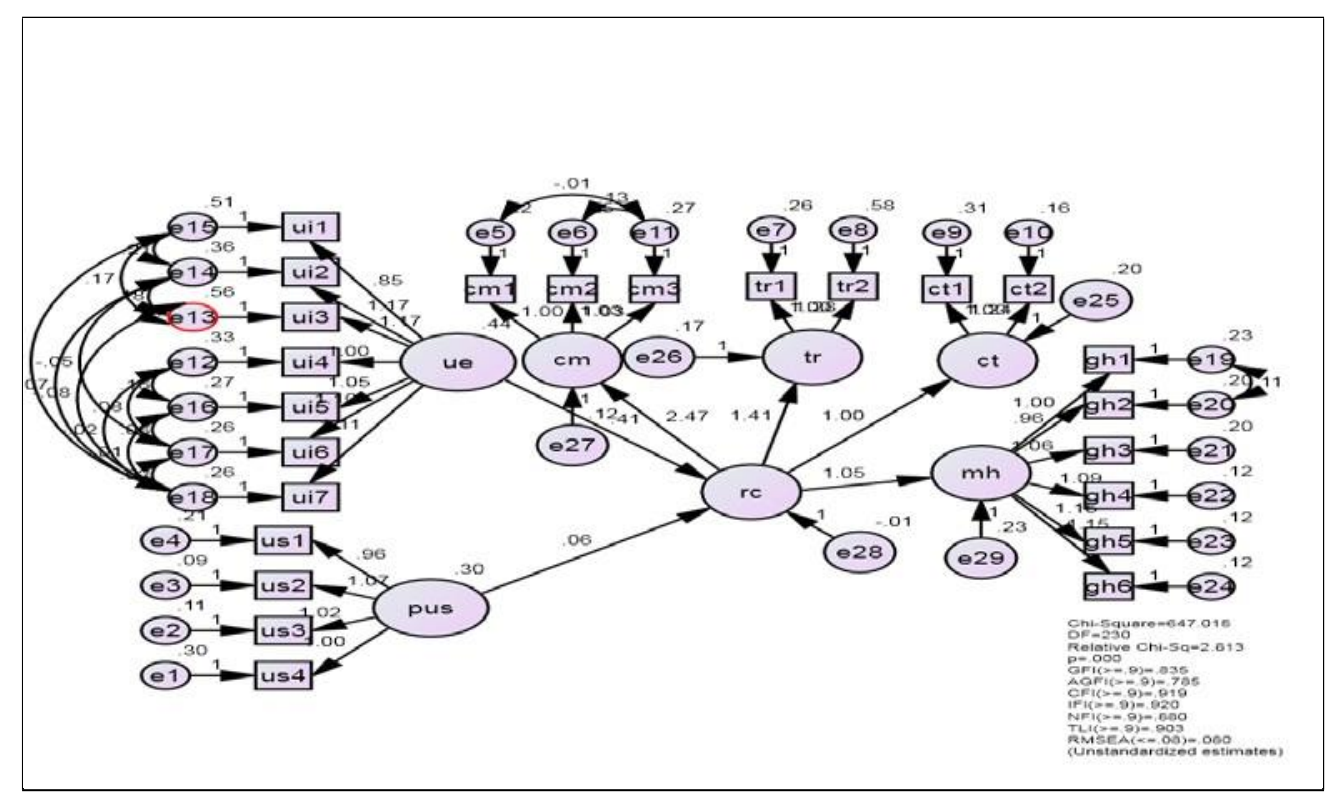

Figure 3: The Regression Path Coefficient for the model

Table 4: Model Fit Indices

\begin{tabular}{|c|c|c|c|c|c|c|}
\hline \multicolumn{7}{|c|}{ Overall Model Fit Indices } \\
\hline & $\chi \mathbf{2 / d . f}$ & GFI & CFI & IFI & TLI & RMSEA \\
\hline $\begin{array}{c}\text { Acceptable } \\
\text { Scale for Good } \\
\text { as well as } \\
\text { Adequate Fit }\end{array}$ & $\leq 5$ & $\geq 0.90$ & $\geq 0.90$ & $\geq 0.90$ & $\geq 0.90$ & $\leq 0.08$ \\
\hline $\begin{array}{c}\text { Composed } \\
\text { Model Fit }\end{array}$ & 2.803 & 0.785 & 0.921 & 0.922 & 0.903 & 0.080 \\
\hline
\end{tabular}

Figure 3 shows the structural model for this study with a good model fit as in Table 4 . The goodness-of-fit statistic meant for validity measurements in this study that consists of the relative $\chi^{2}$ value and the associated d.f., GFI, incremental fit index (IFI), TLI, CFI, and RMSEA. Three items were deleted in order to get the model fit because of poor factor loading (see Table 5).

\section{Convergent Validity}

Convergent validity and discriminant validity was confirmed using cross-loadings, composite reliability and AVE (Average Variance Extracted). AVE defined the amount of variance attained by construct (Fornell \& Larcker, 1981). 
To get satisfactory convergent validity the AVE's value must be at least 0.5 and above. The AVE value represents the ability of the latent variable to describe the variances of its indicators (Goetz, Liehr-Gobbers and Krafft, 2009). Composite reliability has been evaluated to measure the convergent validity of construct in this study. Nunnally and Bernstein (1994) suggested the sufficient value for composite reliability to be more than 0.7 to ensure the accuracy. As shown in Table 3, the composite reliability value for union effectiveness, perceived union support, union relationship capital and mental health is above 0.7 (acceptable range). Since the AVE, composite reliability and factor loadings value of construct fulfill the requirement as mentioned above, it can be said that the convergent validity was established.

Table 5: Item Reliability, Internal Consistency and Convergent Validity

\begin{tabular}{|c|c|c|c|c|c|}
\hline Construct & Item & $\begin{array}{c}\text { Factor } \\
\text { Loading }\end{array}$ & $\begin{array}{l}\text { Cronbach } \\
\text { Alpha }\end{array}$ & $\begin{array}{l}\text { Composite } \\
\text { Reliability }\end{array}$ & $\begin{array}{c}\text { Average } \\
\text { Variance } \\
\text { Extracted }\end{array}$ \\
\hline \multirow{7}{*}{$\begin{array}{l}\text { Union } \\
\text { Effectiveness }\end{array}$} & ui1 & 0.599 & 0.916 & 0.941 & 0.695 \\
\hline & ui2 & 0.763 & & & \\
\hline & ui3 & 0.677 & & & \\
\hline & ui4 & 0.802 & & & \\
\hline & ui5 & 0.839 & & & \\
\hline & ui6 & 0.841 & & & \\
\hline & ui7 & 0.809 & & & \\
\hline \multirow{10}{*}{$\begin{array}{l}\text { Perceived Union } \\
\text { Support }\end{array}$} & us1 & 0.763 & 0.858 & 0.920 & 0.622 \\
\hline & us2 & 0.892 & & & \\
\hline & us3 & 0.846 & & & \\
\hline & us4 & 0.717 & & & \\
\hline & us5 & & & & \\
\hline & us6 & \multirow{2}{*}{\multicolumn{4}{|c|}{$\begin{array}{l}\text { This item was deleted due to poor factor loading } \\
\text { This item was deleted due to poor factor loading }\end{array}$}} \\
\hline & us7 & & & & \\
\hline & us8 & \multicolumn{4}{|c|}{ This item was deleted due to poor factor loading } \\
\hline & us9 & \multicolumn{4}{|c|}{ This item was deleted due to poor factor loading } \\
\hline & us10 & \multicolumn{4}{|c|}{ This item was deleted due to poor factor loading } \\
\hline \multirow{3}{*}{$\begin{array}{l}\text { Union Relationship } \\
\text { Capital }\end{array}$} & $\mathrm{CM}$ & 0.901 & 0.867 & 0.769 & 0.533 \\
\hline & TR & 0.622 & & & \\
\hline & $\mathrm{CT}$ & 0.500 & & & \\
\hline \multirow[t]{6}{*}{ Mental Health } & gh1 & 0.784 & 0.933 & 0.929 & 0.688 \\
\hline & gh2 & 0.792 & & & \\
\hline & gh3 & 0.815 & & & \\
\hline & gh4 & 0.843 & & & \\
\hline & gh5 & 0.861 & & & \\
\hline & gh6 & 0.848 & & & \\
\hline
\end{tabular}

\section{Discriminant Validity}

Discriminant validity was conducted to ensure that the constructed measure is different from other constructs in the model (Hair et al. 2010). Discriminant validity assessed by comparing the square root value of AVE with the correlations between the constructs. The criteria for discriminant validity is the square root value of AVE must bigger that the correlation. Table 6 shows the discriminant validity of the constructs in this study. These results show that all constructs values were higher than the correlations values (off white). Thus, it is evident that the discriminant validity of construct achieved. 
Table 6: The Convergent Validity of Constructs (Results of Average Variance Extracted and Squared Correlations of Each Variable

\begin{tabular}{lrrrr}
\hline & 1 & 2 & 3 & 4 \\
\hline Union Effectiveness & $\mathbf{0 . 6 3 2}$ & & & \\
Perceived Union Support & 0.610 & $\mathbf{0 . 6 7 5}$ & & \\
Union Relationship Capital & 0.602 & 0.629 & $\mathbf{0 . 6 4 8}$ & \\
Mental Health & 0.587 & 0.651 & 0.616 & $\mathbf{0 . 6 8 5}$ \\
\hline
\end{tabular}

Note: The boldface scores on the diagonal are Average Variance Extracted and the off diagonal represent the value of correlation.

\section{Hypotheses Testing: Union effectiveness has significant relationship with union relationship capital}

The result in Table 7 showed the significant relationship between union effectiveness and union relationship capital. Union effectiveness found to have an influence on communication, trust and commitment between the union leaders and union members $(\beta=0.414 ; \mathrm{p}<0.01)$. Therefore $\mathrm{H} 1$ is supported.

Table 7: Path coefficient for union effectiveness and union relationship capital

\begin{tabular}{l|l|l|l|l}
\hline Proposed hypotheses & Hypothesis & Path Coefficient $(\beta)$ & p-value & $\begin{array}{l}\text { Rejected/ } \\
\text { Supported }\end{array}$ \\
\hline $\begin{array}{l}\text { Union Effectiveness } \rightarrow \text { Union } \\
\text { Relationship Capital }\end{array}$ & H1 & 0.414 & $0.000^{*}$ & Supported \\
\hline$*$ significant at $p<0.01$ & & & \\
\hline
\end{tabular}

\section{Hypothesis Testing: Perceived union support has significant relationship with union relationship capital}

This hypothesis is to testing the effect of perceived union support on union relationship capital. Result in Table 8 showed that perceived union support has a positive relationship with communication, trust and commitment between the union leaders and members (union relationship capital). The path coefficient value for this relationship is $\beta=0.057(\mathrm{p}<0.01)$.

Table 8: Path coefficient for union effectiveness and union relationship capital

\begin{tabular}{l|l|l|l|l}
\hline Proposed hypotheses & Hypothesis & $\begin{array}{l}\text { Path Coefficient } \\
(\beta)\end{array}$ & p-value & $\begin{array}{l}\text { Rejected/ } \\
\text { Supported }\end{array}$ \\
\hline $\begin{array}{l}\text { Perceived Union Support } \rightarrow \text { Union } \\
\text { Relationship Capital }\end{array}$ & $\mathrm{H} 2$ & 0.057 & $0.000^{*}$ & Supported \\
\hline$*$ significant at $\mathrm{p}<0.01$ & &
\end{tabular}

* significant at $\mathrm{p}<0.01$

\section{Hypothesis Testing: Communication, trust and commitment between union leaders and union members is interdependent}

One hypothesis was postulated to identify the interaction of communication, trust and commitment between the union leaders and union members in order to increase cohesiveness and strengthening the union. This hypothesis test using Pearson correlation. It is found that communication, trust and commitment have influence to each other. The interdependency of these three elements are: communication influence trust $(r=0.619, p<0.01)$; 
communication influence commitment $(\mathrm{r}=0.611, \mathrm{p}<0.01)$ and trust and commitment $(\mathrm{r}=0.596, \mathrm{p}<0.01)$. These result showed in Table 9.

Table 9: The correlation between communication, trust and commitment

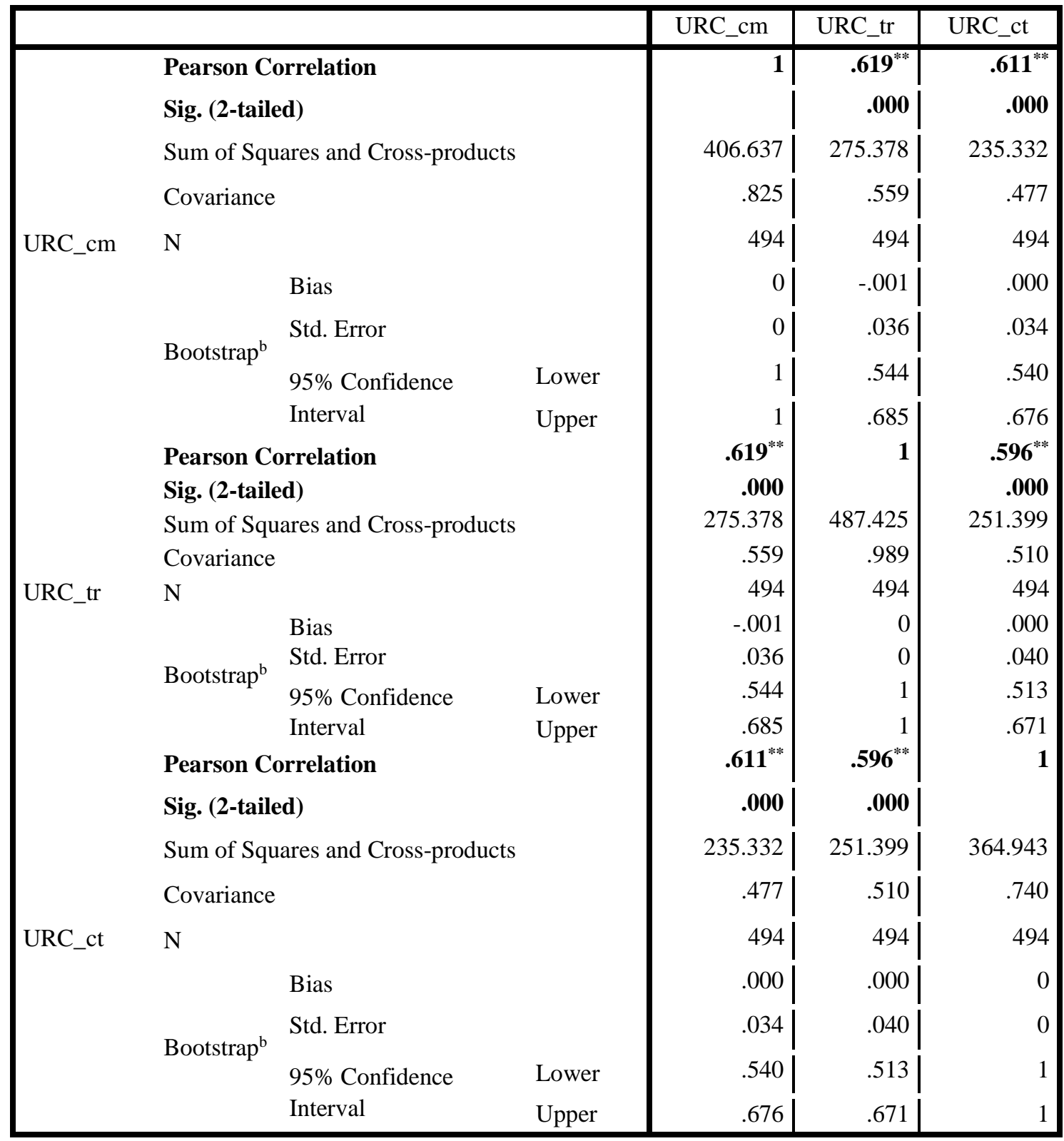

b. Unless otherwise noted, bootstrap results are based on 1000 bootstrap samples

**. Correlation is significant at the 0.01 level (2-tailed).

\section{Hypothesis Testing: Union relationship capital has significant relationship with mental health}

Result showed the positive relationship between union relationship capital and mental health. This result found that effective communication between the union leaders and members can affect trust and commitment within the union. Strong union promotes the positive mental health $(\beta=0.273, \mathrm{p}<0.01)$ in workplace. This result describe in Table 10. 
Table 10: Path coefficient for union relationship capital and mental health

\begin{tabular}{l|l|l|l|l}
\hline Proposed hypotheses & Hypothesis & Estimate & p-value & $\begin{array}{l}\text { Rejected/ } \\
\text { Supported }\end{array}$ \\
\hline $\begin{array}{l}\text { Union Relationship Capital } \rightarrow \\
\text { Mental health }\end{array}$ & $\mathrm{H} 4$ & 0.273 & $0.000^{*}$ & Supported \\
\hline * significant at $\mathrm{p}<0.01$ & & & \\
\hline
\end{tabular}

\section{Hypothesis Testing: Union relationship capital mediates the relationship between union effectiveness, perceived union support and mental health}

Two hypotheses (H5 and H6) were proposed on the mediating effect of union relationship capital. First is H5 that looking at the mediating effect of union relationship capital on the relationship between union effectiveness and mental health. The second hypothesis is looking on the mediating effect of union relationship capital on the relationship between perceived union support and mental health. The results show that both hypotheses are supported (see Table 11).

Table 11: The mediating effect of union relationship capital between union effectiveness, perceived union support and mental health

\begin{tabular}{clccccc}
\hline & & & & Indirect & P & \\
H & Relationship & Path a & Path b & path & values & results \\
\hline H5 & UE $\rightarrow$ URC $\rightarrow$ MH & $0.693(0.044)$ & $0.312(* * *)$ & 0.003 & $* * *$ & Supported \\
H6 & PUS $\rightarrow$ URC $\rightarrow$ MH & $0.478(* * *)$ & $0.426(* * *)$ & 0.011 & $* * *$ & Supported
\end{tabular}

* significant at $\mathrm{p}<0.01$

\section{Discussion}

The objective of this study is to investigate the relationship between union effectiveness, perceived union support, union relationship capital and mental health. Further, this study is to investigate the interdependency between communication, trust and commitment within the union in improving the relationship and strengthening the union. This study also investigates the role of union relationship capital as the mediator between union effectiveness, perceived union support, and mental health. The empirical findings in this study reveal that both union effectiveness and perceived union support is the predictor to union relationship capital that comprises of trust, communication and commitment. This result is consistent with previous studies (Fuller \& Hester 2001; Fullagar, Gallagher et al. 2004; Kuwabara, 2011). Blau (1964) and Kuwabara (2011) in economic exchange theory supports union exchange on tangible elements between members such as between union leaders and members can enhance commitment and trust within parties.

Perceived union support is found to have a direct influence on union relationship capital. This indicate that when the union members perceived their union as supportive and care their well-being, they tend to communicate regularly which increase their commitment and trust towards the union (Shore, Tetrick et al. 1994; Fuller, et al. 2001; Eisenberger, Fasolo \& Davis-Lamastro, 1990; Nyhan 1999; Whitener 2001 Tetrick, Shore et al. 2007). Social exchange theory supported this finding.

As for union relationship capital, this study found that communication, trust, and commitment cannot stand alone without each other. This study is consistent with personal relationship theory (Kelley, 1979) which stressed the interdependence of these elements. The interaction of communication, trust and commitment found to enhance the relationship between the union leaders and members. Furthermore, the interdependency of these elements found to yield outcomes (Davis, \& Love, 2011; Sambasivan et. al, 2011; Ramadass, 2013; 2014) such as mental health. In this study, it was found that when trust, communication and commitment between the union leaders and members (union relationship capital) are very strong, it can lead to positive mental health. 


\section{Implication of Study}

\section{Contribution to Theory and Body of Knowledge}

Union effectiveness, perceived union support and union relationship capital were perceived to have a positive influence on mental health. This study provides new input to the current state of employee participation in terms of how union effectiveness and perceived union support are determinants not only for union commitment but also for union trust and communication (union relationship capital). Further insights on relationships such as union relationship capital as the predictor for mental health in employee participation process were also attained in this study.

This study has illustrated that the important role of union relationship capital between union effectiveness and perceived union support for creating positive mental health in the workplace. The role of union relationship capital as highlighted in this study is important for studying employee participation practice in other countries. In sum, the employee participation research framework of this study provides an understanding of interrelationships within the union among the important variables that have a significant influence on mental health.

\section{Implications for Management}

Firstly, this study identified the four specific elements that are important to the employee participation process in improving mental health: (1) union effectiveness; (2) perceived union support; and (3) union relationship capital: communication, trust and commitment within the trade union. Both union effectiveness and perceived union support play critical roles in influencing union relationship capital for mental health. Additionally, union relationship capital influence mental health. A good state of mental health is determined by good psychological wellbeing. The findings have suggested that policy makers and management may wish to consider all of these elements when dealing with employee participation management. Knowing and understanding these elements help policy makers and management to better organise and oversee an on-going employee participation process, especially in creating and improving the working environment in order to reduce the consequences of poor working environment such as injury, illness and death in the workplace.

Secondly, union effectiveness and perceived union support were observed to be the main factors influencing union relationship capital. What is needed for achieving positive mental health is to emphasise the roles of union effectiveness and perceived union support. Both union effectiveness and perceived union support are basically the union members' perception about their union. Therefore, management should consider cooperating with union leaders in building a positive mental health in workplace.

Thirdly, this study has identified the vital role of union relationship capital in strengthening the union for mental health. The importance of communication, trust and commitment between the union leaders and members is stressed for quality relationship as well as to increase bargaining power. Union leaders should be able to share and disseminate information they gathered with the union members. Effective communication within the union can increase the trade union members' trust towards the union leaders which can affect the trade union members' commitment to the union. Therefore, policy makers should understand the importance of union relationship capital as a critical source of union bargaining power. Hence, policy makers and management may wish to consider assisting and facilitating union relationship capital. 


\section{Conclusion}

\section{Limitations and Directions for Future Research}

Few limitations identified in this study. The sample in this was gathered from manufacturing sector in Peninsular Malaysia. Thus, future research from different sectors such as services, plantation, and transportation is needed. The differenced on the nature of business might have an impact on the union which might have an effect on the employee participation process. Additionally, studies in other sectors are vital to examine if this study can be replicated and generalised to different sectors. The differences in the environment which consist of legislation, culture and politics can influence the industrial relations in countries. For example, Western countries recognise the role of union to bargain on terms and conditions of employment with management. On the other hand, Asian countries tend to limits the union movement that can affect mental health. Thus, the extent of the applicability of union relationship capital in Western and other Asian countries needs further research.

\section{References}

Anderson, J.C. \& Gerbing, D.W.(1988). Structural Equation Modeling in Practice: A Review and Recommended Two - Step Approach. Psychological Bulletin, 103, 411-423.

Aselage, J. \& Eisenberger, R.(2003). Perceived Organizational Support and Psychological Contracts: A Theoretical Integration. Journal of Organizational Behavior, 24: 491-509.

Barling, J., Fullagar, C. \& Kelloway, E.K.(1992). The Union and its Members: A Social Psychological Approach, New York: Oxford University Press.

Bell, S.J. \& Menguc, B.(2002). The Employee-Organization Relationship, OCBs, and Superior Service Quality. Journal of Retailing, 78(2):131-146.

Blau, P.M.(1964). Exchange and Power in Social Life. New York: Wiley.

Burchell, B.(2011). A Temporal Comparison of the Effects of Unemployment and Job Insecurity on Wellbeing. Sociological Research Online. 16(9).

Burton, W.N., Chen, C.Y., Schultz, A.B., \& Edington, D.W.(2008). The Prevalence of Metabolic Syndrome in an Employed Population and the Impact on Health and Productivity. Journal of Occupational and Environmental Medicine. 50:1139-1148.

Chang, C. \& Hsu, P.(2015). The Correlation between Employee Information Literacy and Employee Creativity. Quality and Quantity, 49(1), 221-234.

Chin, W.W.(2010). How to write up and report PLS analyses. In Esposito Vinzi, V., Chin, W.W., Henseler, J. \& Wang, H. (Eds.). Handbook of Partial Least Squares: Concepts, Methods and Applications in Marketing and Related Fields (pp. 655-690). Berlin: Springer.

Clark, P. F.(2009). Building More Effective Unisons. United States of America: Cornell University Press.

Cottini, E. \& Lucifora, C. (2013). Mental Health and Working Conditions in Europe. Industrial \& Labor Relations Review, 66 (4), 958-988

Davis, P. \& Love, P. (2011). Alliance Contracting: Adding Value Through Relationship Development. Engineering, Construction and Architectural Management, 18(5): 444 - 461.

Drucker, P.F.(2007). The Practice of Management. Oxford: Butterworth-Heinemann.

Eisenberger, R., Huntington, R., Hutchison, S. \& Sowa, D.(1986). Perceived Organizational Support. Journal of Applied Psychology, 71: 500-507.

Eisenberger, R., Fasolo, P. \& Davis-Lamastro, V.(1990). Perceived Organizational Support and Employee Diligence, Commitment, and Innovation. Journal of Applied Psychology, 75:51-59.

Fiorito, J.T., \& Jarley, P. (2008). Trade Union Morphology. In Blyton, P., Bacon, N., Fiorito, J., \& Heery, E. (Eds.), The Sage Handbook of Industrial Relations (pp. 189-208). London, England and Thousand Oaks, CA: Sage.

Fuller, J.B., Jr., \& Hester, K.(2001). A Closer Look at the Relationship between Justice Perception and Union Participation. Journal of Applied Psychology, 86: 1096-1105.

Fullagar, C.J., Gallagher, D.G., Clark, P.F \& Carroll, A.E. (2004). Union Commitment and Participation: A 10 Year Longitudinal Study. Journal of Applied Psychology, 89(4): 730-737. 
Fornell, C. \& Larcker,D.F.(1981). Evaluating Structural Equation Models with Unobservable Variables and Measurement Error. Journal of Marketing Research, 18(1):39-50.

Gall, G., \& Fiorito, J.T. (2012). Union Commitment and Activism in Britain and the United States: In Search of Synthesis and Synergy for Renewal. British Journal of Industrial Relations, 50(2), 189-213.

Götz, O., Liehr-Gobbers, K., \& Krafft, M. (2009). Evaluation of Structural Equation Models using the Partial Least Squares (PLS) Approach. In Handbook of Partial Least Squares: Concepts, Methods and Applications.

Gollan, P.J.(2006). Twin Tracks - Employee Representation at Eurotunnel Revisited. Industrial Relations, 45(4):606-649.

Goswami, T.G.(2015). Job Stress and its Effect on Employee Performance in Banking Sector. Indian Journal of Commerce and Management Studies, 6(2), 51-56.

Hair, J.F., Black, W.C., Babin, B.J. \& Anderson, R.E.(2010). Multivariate Data Analysis: Pearson Prentice Hall.

Hayter, S. Fashoyin, T. \& Kochan, T.(2011). Collective Bargaining in the 21st Century. Journal of Industrial Relations. 53(2): 225-247.

Huang, G.H., Niu, X., Lee, C. \& Ashford, S. (2012).Differentiating Cognitive and Affective Job Insecurity: Antecedents and Outcomes. Journal of Organizational Behavior, 33: 752-769. International Labor Organisation (2012): Safety at Work.

Johari, H. \& Ghazali, S.(2011). Exploring Commitment among Union Members: Perspective and Direction. International Review of Business Research Papers, 7(4):104-117.

Kaewanuchit, C., Muntaner, C., \& Isha, N. (2015). A Causal Relationship of Occupational Stress among University Employees. Iranian Journal of Public Health, 44, 931-938.

Kelley, H.H.(1979). Personal Relationships: Their Structures and Processes, Hillsdale, Nj.

Kivimäki, M., Virtanen,,M., Kawachi, I., Nyberg, S.T., Alfredsson, L., Batty, G.D., Bjorner, J.B., Borritz, M., Brunner, E.J., Burr, H., Dragano, N., Ferrie, J.E., Fransson, E.I., Hamer, M., Heikkilä, K. Knutsson, A., Koskenvuo, M., Madsen, I.E.H., Nielsen, M.L., Nordin, M., Oksanen, T., Pejtersen, J.H., Pentti, J., Rugulies, R., Salo, P., Siegrist, J., Steptoe, A., Suominen, S., Theorell, T., Vahtera, J., Westerholm, P.J.M., Westerlund, H., Singh-Manoux, A. \& Jokela. M.(2015). Long Working Hours, Socioeconomic Status, and the Risk of Incident Type 2 Diabetes: A MetaAnalysis of Published and Unpublished Data from 222120 individuals. The Lancet Diabetes \& Endocrinology, 3(1):27-34

Krejcie, R., \& Morgan, D.(1970). Determining Sample Size for Research Activities. Educational and Psychological Measurement, 30(3), 607-610.

Kuwabara, K.(2011). Cohesion, Cooperation, and the Value of Doing Things Together: How Economic Exchange Creates Relational Bonds. American Sociological Review, 76(4);560-580.

Klandermans, B. (1997). The Social Psychology of Protest. Oxford: Blackwell.

Kuruvilla, S., Das, S., Kwon, H., \& Kwon, S.(2002). Union Growth, Decline and Revitalization in Asia. British Journal of Industrial Relations, 403:431-463.

Line, A. \& Lasmane, A.(2014).Leadership Communication and Union Commitment in Latvia: Development Perspectives of Strategic Management. European Integration Studies 8, 141-151

Lo, K. \& Lamm, F. (2005). Occupational Stress in the Hospitality Industry: An Employment Relations Perspective. New Zealand Journal of Employment Relations, 30(1): 23-47.

Loke, S.P., Sambasivan, M. \& Downe, A.G. (2009). Strategic Alliances Outcomes in Supply Chain Environments: Malaysian Case Studies. European Journal of Social Sciences, 9,371-386.

Machin, S. (2000). Union Decline in Britain, British Journal of Industrial Relations, 38, 631-45. Malaysia Social Security Organization Annual Report, 2012.

Mohamed, S., Shamsudin, F.M. \& Johari, H.(2010). Union Organisation and Effectiveness: An Empirical Study on In-House Union in Malaysia. Akademika, 78: 89-94.

Nelson, D., Basu, R., \& Purdie, R. (1998). An Examination of Exchange Quality and Work Stressors in Leader-Follower Dyads. International Journal of Stress Management, 5, 10-112.

Neuman, W.L. (2003). Social Research Methods: Qualitative and Quantitative Approaches. (5 ${ }^{\text {th }}$ Ed.). United States of America: Pearson Education. Inc.

Nunnally, J. C. \& Bernstein, I. H. (1994) Psychometric Theory (3rd ed.). New York, NY: McGraw-Hill, Inc.

Nyhan, R.C. (1999). Increasing Oganizational Affective Commitment In Public Organization. Review of Public Personnel Administration, 19, 58-70.

O'Keefe, L.C., Brown, K.C., \& Christian, B.J. (2014). Policy Perspectives on Occupational Stress. Workplace Health \& Safety, 62(10), 432-8. 
Othmae, K. (1992). Transnational Management, Richard Irwin, Inc, Chicago, Il

Ramadass, S.D., Sambasivan, M. \& Xavier, J.H. (2013). The Role of Relationship Capital in Malaysian Public Sector Collaboration Outcomes. Journal of Business And Policy Research, 8(3):191-203.

Ramadass, S.D. (2014). Perceived Success Factors Affecting Public Sector Collaboration Outcome in Malaysia. Graduate School of Management, Universiti Putra Malaysia.

Rhoades, L. \& Eisenberger, R. (2002). Perceived Organizational Support: A Review of the Literature. Journal of Applied Psychology, 87: 698-714.

Loke, S.P., Sambasivan, M. \& Downe, A.G. (2009). Strategic Alliances Outcomes in Supply Chain Environments: Malaysian Case Studies. European Journal of Social Sciences, 9,371-386.

Sambasivan, M., Loke, S.P., Mohamed, Z.A. \& Leong, Y.C. (2011). Impact of Interdependence between Supply Chain Partners on Strategic Alliance Outcomes: Role of Relational Capital as aMediating Construct. Management Decision, 49(4): 548-569.

Sharifzadeh, M., \& Almaraz, J. (2014). Happiness and Productivity in the Workplace. American Journal of Management, 14(4), 19.

Shore, L.M., Tetrick, L.E., Sinclair, R.R. \& Newton, L.A. (1994). Validation of a Measure of Perceived Union Support. Journal of Applied Psychology, 79(6): 971-977.

Sirisunhirun, S. \& Dhirathiti, N.S. (2015). Job Characteristics and a Happy Workplace in Thai Higher Education Institutions. The Organization Development Journal. 33(1), 71-89.

Sjöberg, O. (2010) Social Insurance as a Collective Resource: Unemployment Benefits, Job Insecurity and Subjective Wellbeing in a Comparative Perspective. Social Forces 88: 1281-1304.

Smith, P.M, Black, O., Keegel, T. \& Collie, A.(2014). Are the Predictors of Work Absence Following a Work-Related Injury Similar for Musculoskeletal and Mental Health Claims?. J. Occup Rehabil. 24(1):79-88.

Soehod, K. \& Lekha, L.K.P. (2007). Law on Safety and Health in Malaysia. Project Report Universiti Teknologi Malaysia.

Sveinsdóttir, H., Biering, P. \& Ramel, A. (2006). Occupational Stress, Job Satisfaction, and Working Environment among Icelandic Nurses: A Cross-Sectional Questionnaire Survey. International Journal of Nursing Studies, 43(7):875-889.

Tayama, J., Li, J., \& Munakata, M. (2016). Working Long Hours is Associated with Higher Prevalence of Diabetes in Urban Male Chinese Workers: The Rosai Karoshi Study. Stress \& Health: Journal ofThe International Society For The Investigation of Stress, 32(1), 84-87.

Tetrick, L.E.,Shore, L.M., Mcclurg, L. \& Vandenberg, R.J. (2007). A Model of Union Participation: The Impact of Perceived Union Support, Union Instrumentality, and Union Loyalty. Journal of Applied Psychology, 92(3): 820-828.

Valcour, M. (2007). Work-Based Resources as Moderators of the Relationship between Work Hours and Satisfaction with Work-Family Balance. Journal of Applied Psychology, 92,1512-1523.

Williams, J.R., \& Rosenstock, L. (2015). Squeezing Blood from a Stone: How Income Inequality Affects the Health of the American Workforce. American Journal of Public Health, 105(4), 616-621.

Wilson, M.G., Dejoy, D.M., Vandenberg, R.J., Richardson, H.A. \& Mcgrath, A.L.(2004). Work Characteristics and Employee Health and Well-Being: Test of a Model of Healthy Work Organization. Journal of Occupational and Organizational Psychology. 77, 565-589.

Whitener, E.M.(2001). Do High Commitment Human Resource Practices Affect Employee Commitment: A Cross-Level Analysis Using Hierarchical Linear Modeling. Journal of Management Decision, 27:515-537. 